\title{
THE PROPROTEIN CONVERTASE PC2 IS INVOLVED IN THE MATURATION OF PROSOMATOSTATIN TO SOMATOSTATIN-14 BUT NOT IN THE SOMATOSTATIN DEFICIT IN ALZHEIMER'S DISEASE
}

\author{
R. WINSKY-SOMMERER, ${ }^{\text {a }}$ D. GROUSELLE, \\ C. ROUGEOT, ${ }^{b}$ V. LAURENT, ${ }^{c}$ J.-P. DAVID, ${ }^{d}$ \\ A. DELACOURTE, ${ }^{e}$ P. DOURNAUD, ${ }^{a}$ N. G. SEIDAH, ${ }^{f}$ \\ I. LINDBERG, ${ }^{\mathrm{c}}$ S. TROTTIER ${ }^{\mathrm{a}}$ AND J. EPELBAUM ${ }^{\mathrm{a} *}$ \\ aINSERM U549, IFR Broca-Sainte Anne, Centre Paul Broca, 2 ter rue \\ d'Alésia, 75014 Paris, France \\ ${ }^{b}$ Unité de Génétique et Biochimie du Développement, Département \\ d'Immunologie, Institut Pasteur, Paris, France \\ cDepartment of Biochemistry and Molecular Biology, Louisiana State \\ University Medical Center, New Orleans, LA 70112, USA \\ ${ }^{d}$ Centre hospitalier Emile Roux, Limeil Brévannes, France \\ ${ }^{e}$ Cité Hospitalière, 1 place de Verdun, 59045, INSERM U422, Lille, \\ France \\ 'Laboratory of Biochemical Neuroendocrinology, IRCM, Montréal, \\ Quebec, Canada \\ IINSERM U573, IFR Broca-Sainte Anne, Centre Paul Broca, Paris, \\ France
}

\begin{abstract}
A somatostatin deficit occurs in the cerebral cortex of Alzheimer's disease patients without a major loss in somatostatin-containing neurons. This deficit could be related to a reduction in the rate of proteolytic processing of peptide precursors. Since the two proprotein convertases (PC)1 and PC2 are responsible for the processing of neuropeptide precursors directed to the regulated secretory pathway, we examined whether they are involved first in the proteolytic processing of prosomatostatin in mouse and human brain and secondly in somatostatin defect associated with Alzheimer's disease. By size exclusion chromatography, the cleavage of prosomatostatin to somatostatin-14 is almost totally abolished in the cortex of PC2 null mice, while the proportions of prosomatostatin and somatostatin-28 are increased. By immunohistochemistry, PC1 and PC2 were localized in many neuronal elements in human frontal and temporal cortex. The convertases levels were quantified by Western blot, as well as the protein 7B2 which is required for the production of active PC2. No significant change in PC1 levels was observed in Alzheimer's disease. In contrast, a marked decrease in the ratio of the PC2 precursor to the total enzymatic pool was observed in the frontal cortex of Alzheimer patients. This decrease coincides with an increase in the
\end{abstract}

*Corresponding author. Tel: +33-1-4078-9282; fax: +33-1-45807293.

E-mail address: epelbaum@broca.inserm.fr (J. Epelbaum).

Abbreviations: AD, Alzheimer's disease; AMC, aminomethylcoumarinamide; $\mathrm{B}$, borderline; $\mathrm{C}$, control; $\mathrm{CT}$, carboxy terminal; HPLC, high pressure liquid chromatography; IR, immunoreactive/immunoreactivity; MD, mixed dementia; PAGE, polyacrylamide gel electrophoresis; PBS, phosphate-buffered saline; PC, proprotein convertase; RIA, radioimmunoassay; RER, rough endoplasmic reticulum; RT, room temperature; SDS, sodium dodecyl sulfate; SRIF, somatostatin; TBS-T, Tris $50 \mathrm{mM}, \mathrm{NaCl} 150 \mathrm{mM}, \mathrm{pH}$ 7.5 , containing $0.1 \%$ Tween-20; TGN, trans-Golgi network; WT, wild type. binding protein 7B2. However, the content and enzymatic activity of the PC2 mature form were similar in Alzheimer patients and controls. Therefore, the cortical somatostatin defect is not due to convertase alteration occuring during Alzheimer's disease. Further studies will be needed to assess the mechanisms involved in somatostatin deficiency in Alzheimer's disease. @ 2003 IBRO. Published by Elsevier Ltd. All rights reserved.

Key words: Alzheimer's disease, somatostatin, proprotein convertases, 7B2, post-translational processing, frontal cortex.

Alzheimer's disease (AD) is an age-associated neurodegenerative illness characterized by a progressive decline of cognitive and behavioral processes. The characteristic dementia of Alzheimer-type is most likely due to pathologic changes that involve neocortical areas (Cummings, 1987; Cummings et al., 1987). In addition to the cholinergic and other classical neurotransmitter systems, various neuropeptides that occur in cortical and subcortical brain regions play a role as modulators of cognitive and behavioral processes (Bennett et al., 1997). Therefore, numerous studies aimed to determine whether neuropeptidergic systems were affected in AD. The most significant changes are those reported for somatostatin (SRIF). Selective decreases of SRIF have been described in AD cerebral cortex (Perry et al., 1981; Reinikainen et al., 1987; Beal, 1990; Bissette and Myers, 1992; Rubinow et al., 1992; Sadow and Rubin, 1992; Ang and Shul, 1995). Furthermore, the cortical SRIF deficiency correlated with the dementia score in frontal cortex (Dournaud et al., 1995) and with some indices of severity of the illness (Leake et al., 1991).

Neuropeptides are synthesized as large inactive polypeptide precursors which undergo endoproteolytic cleavage at specific basic residue sites to produce biologically active peptides. In mammalian species, this conversion is often mediated by a family of serine proteinases related to the subtilisin/kexin-type, and known as proprotein convertases (PCs) (Seidah and Chretien, 1999). Analysis of the tissue expression and cellular localization of the $\mathrm{PCs}$ has revealed that, among the seven known mammalian PCs, only PC1 and PC2 expression is restricted to endocrine cells and neurons. In a previous study, we reported the regional and cellular localization of PC1 and PC2 in rat brain by immunohistochemistry, demonstrating that both convertases are well poised to process protein precursors into biologically active end-products within the mammalian brain (Winsky-Sommerer et al., 2000). In vitro co-expression studies and results obtained on pancreatic 
Table 1. Patient characteristics: clinical and neuropathological data

\begin{tabular}{|c|c|c|c|c|c|c|c|c|}
\hline \multirow[t]{2}{*}{ Diagnosis } & \multicolumn{2}{|c|}{ apoE genotype } & \multirow[t]{2}{*}{ Age } & \multirow{2}{*}{$\begin{array}{l}\text { PMD, } \\
\text { hours }\end{array}$} & \multirow[t]{2}{*}{ MMS } & \multirow{2}{*}{$\begin{array}{l}\text { CDR } \\
\text { range }\end{array}$} & \multirow{2}{*}{$\begin{array}{l}\text { Amyloid burden, } \\
\mu \mathrm{g} \mathrm{A} \beta / \mathrm{g} \text { of tissue }\end{array}$} & \multirow{2}{*}{$\begin{array}{l}\text { tau Stages, } \\
\text { arbitrary units }\end{array}$} \\
\hline & $\varepsilon 2 / \varepsilon 3$ & $\varepsilon 4$ & & & & & & \\
\hline $\mathrm{C}(n=7)$ & $n=6$ & $n=1$ & $86.4 \pm 2.3$ & $17.4 \pm 5.5$ & $27.6 \pm 0.8 \quad(n=7)$ & $0.0-0.5$ & $10.1 \pm 3.5$ & $4.9 \pm 0.9$ \\
\hline $\mathrm{B}(n=6)$ & $n=4$ & $n=2$ & $89.2 \pm 1.4$ & $29.3 \pm 10.4$ & $20.8 \pm 1.5 \quad(n=5)$ & $0.5-1.0$ & $16.8 \pm 3.8$ & $6.3 \pm 0.4$ \\
\hline $\mathrm{MD}(n=4)$ & $n=1$ & $n=3$ & $92.0 \pm 3.2$ & $15.0 \pm 3.6$ & $6.7 \pm 3.4^{\#} \quad(n=3)$ & $2.0-3.0$ & $21.3 \pm 8.0$ & $7.8 \pm 0.5^{*}$ \\
\hline $\mathrm{AD}(n=7)$ & $n=3$ & $n=4$ & $90.0 \pm 3.5$ & $24.1 \pm 6.8$ & $12.0 \pm 3.9^{* *, \#}(n=6)$ & $1.0-3.0$ & $98.2 \pm 24.4^{\star * *, \# \#, \gamma}$ & $8.9 \pm 0.5^{\star \star, \#}$ \\
\hline
\end{tabular}

${ }^{*} P<0.05$; ${ }^{* *} P<0.001$; ${ }^{* * *} P<0.0001$ versus $\mathrm{C}$; ${ }^{\#} P<0.05$; ${ }^{\# \# ~} P<0.001$; \#\#\# $P<0.0001$ versus $\mathrm{B} ;{ }^{\gamma} P<0.05$ versus MD.

apoE, apolipoprotein E; CDR, clinical dementia rating score; MMS, Mini-Mental State examination; PMD, postmortem delay.

tissue from $\mathrm{PC} 2$ null $\left(\mathrm{PC}^{-1-}\right)$ mice indicated that $\mathrm{PC} 1$ and $\mathrm{PC} 2$ are involved in the production of the different bioactive peptides derived from proSRIF (Galanopoulou et al., 1993; Perone et al., 1996; Furuta et al., 1997). Mammalian proSRIF harbors two basic sites $\left(R_{88}\right.$ and $\left.R_{101}-K_{102}\right)$. Endoproteolytic cleavage at these mono- and dibasic sites produces the two bioactive forms SRIF28 and SRIF14, respectively.

PC1 and PC2 are initially synthesized as proenzymes which undergo activation by cleavage of their respective proregions (for review, see Muller and Lindberg, 1999). In endocrine cell lines, proPC1 autocatalytically cleaves its prosegment within the rough endoplasmic reticulum (RER). In contrast, proPC2 requires for its activation a specific binding protein known as 7B2 (Zhu and Lindberg, 1995) for the synthesis of an activatable precursor. 7B2 is a small acidic protein with a strictly neuroendocrine distribution (Marcinkiewicz et al., 1986). In cell studies, it has been shown that after biosynthesis, uncleaved 7B2 (27 kDa) and proPC2 (75 kDa) are associated within the RER. This complex reaches the trans-Golgi network (TGN), where 7B2 is internally cleaved into a $21 \mathrm{kDa}$ fragment and a carboxy-terminal peptide (CT peptide $\mathrm{Pa}$ quet et al., 1994). PC2 propeptide removal does not appear to require 7B2 association. However, if proPC2 has not encountered 7B2, catalytically active PC2 cannot be generated (Zhu, and Lindberg, 1995; Muller et al., 1997). Moreover, uncleaved 7B2 as well as the CT peptide have been demonstrated to act as nanomolar inhibitors of PC2 (Martens et al., 1994; Lindberg et al., 1995).

In the present study, we first analyzed by chromatography prosomatostatin processing in the cortex of PC2 null $\left(P C 2^{-1-}\right)$ mice compared to wild-type control mice (WT). Then, PC1 and PC2 expressing cells and fibers were localized in the human frontal and temporal cortex by immunohistochemistry. To determine whether PC1, PC2 and its binding protein 7B2 may be altered in $A D$, convertase amounts and molecular weight species, as well as PC2 activity, were compared in three distinct groups of patients displaying a progressive severity of cognitive and behavioral impairments and in aged control subjects.

\section{EXPERIMENTAL PROCEDURES}

\section{Patients' characteristics, animal tissues and sample preparations}

Postmortem tissues. Twenty-four patients were examined in the present study (seven men and 17 women), among them seven controls, six patients with mild cognitive impairments or very mild dementia and 11 demented patients. Average age was $89 \pm 7$ years (range, $78-106$ years). Table 1 gives a synopsis of clinical, neuropathological and biochemical data of the cases. The cohort was from one geriatric department and all patients died at the hospital (Emile Roux Hospital, Limeil Brévannes, France). They were examined by a neurologist and underwent a neuropsychological assessment every 6 months and each subject included in this study was assessed in the 6 months prior to death. Cognitive status was evaluated using the Mini- Mental State Examination of Folstein (Folstein et al., 1975) and the Clinical Dementia Rating score (Hughes et al., 1982). For the demented patients, the National Institute of Neurological Disorders and Stroke-Alzheimer's disease and Related Disorders Association criteria (McKhann et al., 1984) and the modified Hachinski score (Moroney et al., 1997) were evaluated to specify the etiology as probable AD or mixed dementia, respectively. Moreover, laboratory investigation, including computed tomography scan, electroencephalogram, and a panel of biological tests (syphilis, human immunodeficiency virus, vitamin $B_{12}$ and folate levels, calcemia and thyroid function tests), was achevied for each patient in order to screen treatable causes of dementia. The onset of the disease was also recorded. The clinical diagnosis of probable AD suspected was histopathologically confirmed after autopsy by the detection of neurofibrillary tangles and neuritic plaques in cortical and subcortical areas. Patients suffering from other neurodegenerative disease (i.e. dementia with Lewy bodies, other parkinsonian syndromes or frontotemporal dementia) were excluded from this study. Patients were classified in four groups: $A D(n=7)$, mixed dementia (AD with a strong vascular involvement revealed after paraclinical investigations, MD; $n=4$ ), borderline (patients with very mild dementia or mild cognitive impairment; $\mathrm{B} ; n=6)$ and controls (C; $n=7$ ).

For each patient, the apolipoprotein $\mathrm{E}$ genotyping was recorded. Neurofibrillary tangles and phosphorylated tau proteins were semi-quantified as previously reported (Delacourte et al., 1999). Progression of neurofibrillary degeneration was categorized into 10 stages according to the brain regions affected (Delacourte et al., 1999). Amyloid plaques and $\beta$-amyloid peptides were also detected (Delacourte et al., 1999).

Brains were obtained at autopsy. Frontal cortex (Brodmann area A9) dissections were carried out by the same investigators, guided by the atlas Human Central Nervous System (Nieuwenhuys et al., 1988).

For chromatography and RIA analysis, brain tissues from three WT and three $\mathrm{PC}^{-1-}$ mice (Furuta et al., 1997) were dissected and frontal cortex samples were extracted in $2 \mathrm{~N}$ acetic acid supplemented with a Complete protease inhibitor cocktail tablet (Roche Diagnostics, Mannheim, Germany) and frozen at $-80^{\circ} \mathrm{C}$ for $48 \mathrm{~h}$. Samples were then centrifuged and supernatants lyophilized.

For Western blot analysis, Brodmann area 9 samples $(n=24$; 45-230 mg) were homogenized with three volumes (vol/wt) of extraction buffer $(50 \mathrm{mM}$ Tris- $\mathrm{HCl} \mathrm{pH} 7.5,150 \mathrm{mM} \mathrm{NaCl}, 1 \%$ Nonidet P40, $0.5 \%$ sodium deoxycholate, $0.1 \%$ sodium dodecyl sulfate [SDS]) freshly supplemented with a Complete protease 
inhibitor cocktail tablet (Roche Diagnostics). The extracts were then centrifuged at $14,000 \times g$ for $30 \mathrm{~min}$ at $4{ }^{\circ} \mathrm{C}$. The supernatants were used as the soluble fraction and protein concentrations were determined by BCA Protein Assay kit (Pierce, Rockford, USA) according to the manufacturer's instructions. Frontal cortex from an adult male Sprague-Dawley rat killed by decapitation was also extracted in order to be used as internal standard in the Western blot experiments. All human and rat samples were processed at the same time. All animal procedures complied with French laws regarding animal experimentation (Decree No. 87-848, October 19, 1987 and the Ministerial Decree of April 19, 1988). The number of animals used was minimized as well as their suffering.

For the PC2 enzyme assay, Brodmann area 9 samples $(n=$ $24 ; 82-317 \mathrm{mg}$ ) were homogenized on ice in $0.1 \mathrm{M}$ sodium acetate buffer ( $\mathrm{pH} 5.0)$, containing $1 \%$ Triton $\mathrm{X}-100,1 \mu \mathrm{M}$ pepstatin, $1 \mu \mathrm{M}$ transepoxysuccinic acid (E64) and $1 \mathrm{mM}$ phenylmethylsulfonylfluoride. The homogenates were then centrifuged at $13,000 \times g$ for $10 \mathrm{~min}$ at $4{ }^{\circ} \mathrm{C}$ and the supernatants collected for use as the enzyme source (see below).

Biopsy tissues. For immunohistochemistry, samples of cerebral cortex were obtained during epilepsy surgery for drugresistant partial chronic seizures from three patients (two men, 29 and 31 years old, and one woman, 29 years old). None of the patient had experienced seizure just before anesthesia. The limits of the epileptogenic area were identified by stereotaxic electroencephalography recordings (Bancaud et al., 1975). The region of brain resection included the area of seizure onset and the immediate surrounding regions where ictal discharges secondarily propagated. Cortical blocks were selected in the propagation areas: two samples were located in the second temporal gyrus, and one sample in the middle frontal gyrus.

The tissues were fixed immediately after surgical removal with $4 \%$ paraformaldehyde in $0.1 \mathrm{M}$ phosphate buffer, $\mathrm{pH} 7.4$ for $8 \mathrm{~h}$ at $4{ }^{\circ} \mathrm{C}$. They were sequentially rinsed and cryoprotected in a series of sucrose solutions ( 10 to $20 \%$ ) for $48 \mathrm{~h}$ at $4{ }^{\circ} \mathrm{C}$, frozen in liquid isopentane at $-45{ }^{\circ} \mathrm{C}$, and then stored at $-80{ }^{\circ} \mathrm{C}$ until immunohistochemical experiments.

\section{HPLC chromatography analysis}

Each extracted sample was analyzed using a HPLC system (Spectra-Physics, SP8000) connected to a Superdex Peptide column (HR10/30; Pharmacia Biotech). Exclusion chromatography was performed in water containing $0.1 \%$ trifluoroacetic acid and $0.01 \%$ Triton $\mathrm{X}-100$ at a flow rate of $0.75 \mathrm{ml} / \mathrm{min}$. Fractions of $0.75 \mathrm{ml}$ were collected and tested after lyophilization for their somatostatin content.

\section{Radioimmunossay procedure}

On the day of the assay, fraction samples were resuspended in RIA buffer. TyrO-SRIF14 (Peninsula, Mercyside, UK) was iodinated and purified as previously described (Rorstad, et al., 1979). Fraction samples or SRIF standards were incubated with the antibody, used at a $1 / 60,000$ final dilution, for $24 \mathrm{~h}$ at $4{ }^{\circ} \mathrm{C}$. [125I]TyrO-SRIF14 (20,000 count/min) was added for a further $24 \mathrm{~h}$ period. Separation of complex from free ligand was obtained by centrifugation, using a horse anti-rabbit gamma globulins (1/750 final dilution; Biosys, Compiègne, France). The specificity of the antiserum for SRIF against various peptides and neurotransmitters has been evaluated previously. Moreover, this SRIF antibody crossreacts with SRIF14, SRIF28 and proSRIF but not with cortistatin (Grouselle et al., 1998).

\section{Antibodies used for immunohistochemistry and Western blot analysis}

Polyclonal antibodies directed against the mouse PC1 C-terminal amino acid sequence (629-726) and the C-terminal segment of the mouse PC2 (amino acids 529-537) were used for immunohistochemical and Western blot experiments (Benjannet et al., 1992). The polyclonal antiserum against 7B2 was raised against the sequence 23-39 of human 7B2 (Zhu and Lindberg, 1995). An affinity-isolated antigen-specific antibody directed against the actin protein (Sigma-Aldrich, Inc., St. Louis, MO, USA) was used as a reference protein for semi-quantification of the Western blots.

\section{Immunohistochemical procedure}

Cryostat sections of $12 \mu \mathrm{m}$ thickness were mounted on superfrost slides. Sections of $40 \mu \mathrm{m}$ were also cut and collected in cold $0.1 \mathrm{M}$ phosphate-buffered saline (PBS), $\mathrm{pH}$ 7.4. Slides and free-floating sections were both rinsed in PBS for $30 \mathrm{~min}$, and treated either 10 min in $0.5 \%$ hydrogen peroxide diluted in PBS for the slides, or $20 \mathrm{~min}$ in $1.5 \%$ hydrogen peroxide for the free-floating sections. After several washes in PBS, they were sequentially preincubated in a blocking solution, containing $0.02 \mathrm{M}$ PBS, $0.2 \%$ gelatin, $10 \%$ normal goat serum, $0.25 \%$ Triton $\mathrm{X}-100$, for $30 \mathrm{~min}$ at $4{ }^{\circ} \mathrm{C}$, and then incubated overnight at $4{ }^{\circ} \mathrm{C}$ in the PC1 or PC2 primary antisera diluted either 1:5000 or 1:8000 in blocking solution. Sections were then rinsed in $0.02 \mathrm{M} \mathrm{PBS}, 0.2 \%$ gelatin, $0.25 \%$ Triton X-100 and incubated for $30 \mathrm{~min}$ at room temperature (RT) in biotinylated goat anti-rabbit antibody (BioGenex, San Ramon, CA, USA) diluted 1:100 in blocking solution. Subsequently, they were washed for $30 \mathrm{~min}$, and incubated in streptavidin-horseradish peroxidase diluted 1:100 in blocking solution for $30 \mathrm{~min}$ at RT. Sections were finally immunostained with the fluorescein-Tyramide Signal Amplification system (NEN Life Science Products, Boston, MA, USA), and washed three times $10 \mathrm{~min}$ in $0.1 \mathrm{M}$ PBS. Free floating sections were mounted on superfrost slides. All slides were air-dried and coverslipped with buffered glycerol.

Immunohistochemical controls included omission of the primary antibodies or the intermediate reagents from the immunohistochemical procedure. The specificity of $\mathrm{PC} 1$ and $\mathrm{PC} 2$ primary antisera in immunohistochemical procedures has been previously reported (Winsky-Sommerer et al., 2000). Moreover, in order to control the reproducibility of staining, the immunohistochemical experiment was repeated four times. Similar results were obtained with sections of $12 \mu \mathrm{m}$ and $40 \mu \mathrm{m}$ thickness. Finally, adjacent sections were stained with Cresyl Violet to evaluate the cytoarchitecture of the samples. No histopathological abnormality was observed.

\section{Western blot analysis}

Each blot included a standard set of sample dilutions to ensure linearity of antibody binding and detection. A range of 1 to $20 \mu \mathrm{g}$ and 10 to $40 \mu \mathrm{g}$ of the soluble fraction was used for the rat cortex and each human sample, respectively. These aliquots were mixed with sample buffer $(0.0625 \mathrm{M}$ Tris- $\mathrm{HCl} \mathrm{pH} 6.8,10 \%$ glycerol, $2 \%$ SDS, $5 \% \beta$-mercaptoethanol, $0.001 \%$ Bromophenol Blue) and boiled for $5 \mathrm{~min}$. SDS-polyacrylamide gel electrophoresis (PAGE) was performed either on $8 \%$ (for PC1 and PC2 immunodetection) or $12 \%$ (for 7B2 immunodetection) polyacrylamide gels (Laemmli, 1970). Proteins were electrotransferred to Polyscreen membranes (NEN Life Sciences Products) at $125 \mathrm{~mA}$ for $1 \mathrm{~h}$ at $4{ }^{\circ} \mathrm{C}$. The blots were blocked in $5 \%$ non fat-dry milk/TBS-T (Tris $50 \mathrm{mM}, \mathrm{NaCl}$ $150 \mathrm{mM}$, pH 7.5 containing $0.1 \%$ Tween-20) for $1 \mathrm{~h}$ at RT. Membranes were then incubated with primary antisera: PC1, PC2 and 7B2 antibodies were respectively diluted 1:2500, 1:3000 and $1: 2500$ in $0.5 \%$ non fat-dry milk/TBS-T containing the actin antibody diluted 1:1500. Incubation was performed overnight at $4{ }^{\circ} \mathrm{C}$, followed by three washing steps in TBS-T. Membranes were then incubated $30 \mathrm{~min}$ at RT with peroxidase-conjugated, affinity-isolated, swine anti-rabbit immunoglobulins (Dako, Glostrup, Denmark) diluted 1:5000 in blocking solution, and washed three times $15 \mathrm{~min}$ in TBS-T. Blots were finally developed using enhanced 
chemiluminescence (Renaissance; NEN Life Science Products) according to the manufacturer's instructions.

The specificity of the PC1 and PC2 antisera has been previously reported in Western blot procedures (Benjannet et al., 1993; Marcinkiewicz et al., 1993; Winsky-Sommerer et al., 2000). For 7B2, the specificity of staining was confirmed by immunoabsorbing the primary antibody with $5 \mu \mathrm{M}$ of synthetic 7B2 peptide (fragment 23-39) (Peninsula) on rat and human soluble fractions (one control and one AD patient).

Semi-quantification of the immunoblots was performed using a computer-assisted scanning system and the NIH Image 1.62 software (densitometric analysis of 1-D gels program; NIH Image Web site http://rsb.info.nih.gov/nih-image/). Adjustment for densitometric values from one blot to another was made by correcting all values to the rat cortex internal standard. Protein levels in each sample were obtained by calculating the mean of densitometric values obtained for two loaded quantities. PC1, PC2 and 7B2 protein levels were then normalized to the internal $40 \mathrm{kDa}$ actin protein band detected simultaneously in each sample. The data obtained were expressed as arbitrary units. The densitometric values of the bands were found to be linearly correlated to the protein amounts in the range used for the experiments (linear regression coefficients were for rat cortex $r^{2}=0.997$ and $r^{2}=0.944$ respectively on $\mathrm{PCs}$ and $7 \mathrm{~B} 2$ blots, and $0.902<\mathrm{r}^{2}<0.989$ for human samples).

\section{PC2 enzyme assay}

The assay was performed in $50 \mu \mathrm{l}$ final volume containing $100 \mu \mathrm{g}$ of proteins in $100 \mathrm{mM}$ sodium acetate $\mathrm{pH} 5.0$, containing $5 \mathrm{mM}$ calcium chloride, $0.2 \%$ octyl glucoside and $0.5 \%$ Triton $\mathrm{X}-100$. A proteinase inhibitor cocktail composed of $1 \mu \mathrm{M}$ pepstatin, $1 \mu \mathrm{M}$ $\mathrm{E}-64,0.28 \mathrm{mM} n$-tosyl-L-lysine chloromethyl ketone and $0.14 \mathrm{mM}$ L-I-tosylamide 2- phenylethyl chloromethyl ketone was added to the mixture. The incubations were performed at $37{ }^{\circ} \mathrm{C}$ in the presence of Arg-Thr-Lys-Arg-methylcoumarinamide as a substrate at a final concentration of $200 \mu \mathrm{M}$. The liberation of the fluorescent product aminomethylcoumarinamide (AMC) was monitored with a 96-well fluorometer (excitation $380 \mathrm{~nm}$, emission 460 $\mathrm{nm}$; Lab Systems, Austin, USA), and the amount of released AMC was calculated by reference to a free AMC standard curve. PC2 activity was measured in triplicate. Results are the mean of the three determinations \pm S.E.M. and are reported in pmol released $\mathrm{AMC} / 100 \mu \mathrm{g}$ protein.

\section{Statistical analysis}

Data were statistically analyzed by analysis of variance and linear regressions were performed (two-tailed $P$ value and Pearson's correlation coefficient $r$ ) using the program Statview (Statview software, Abacus Concepts, Berkeley, USA).

\section{RESULTS}

\section{Prosomatostatin processing in $\mathrm{PC2}^{-1-}$ mice}

We first studied whether prosomatostatin processing was affected by the lack of PC2 gene product in mice. Analysis by radioimmunoassay for somatostatin components in cortical extracts after size fractionation by HPLC chromatography showed that for WT mice the major prosomatostatinderived peptide was SRIF14 (Fig. 1A). ProSRIF and SRIF28 were also detected in these cortical extracts. A fourth minor peak corresponding to a non-characterized somatostatin-related form $(x)$ was also observed. In $\mathrm{PC} 2^{-1-}$ extracts the same four somatostatin- related forms were detected compared to the corresponding controls. However, SRIF14 was nearly completely absent in the cortex of $\mathrm{PC}^{-1-}$ mice (Fig. 1A).

As shown in Fig. 1B, the total somatostatin-like immunoreactivity was similar in knockout mice and their corresponding WT controls. The concentrations of proSRIF and SRIF28 were significantly increased in $\mathrm{PC}^{-1-}$ extracts $(P<0.05)$, while SRIF14 contents were significantly decreased $(P<0.001)$. The levels of the non-characterized $\mathrm{x}$ peptide were similar in WT and knockout mice. Hence, SRIF14 represented less than $5 \%$ of the total somatostatin-like immunoreactivity contained in cortical tissue in the absence of PC2, while it represented $45 \%$ in WT mice (Fig. 1C). In contrast, SRIF28 is the major end-product of prosomatotatin processing in $\mathrm{PC}^{-1-}$ cortical extracts (Fig. 1C).

These results indicate that in vivo cleavage at the dibasic site $R_{101}-K_{102}$ to yield SRIF14 requires PC2, whereas cleavage at the monobasic residue $R_{88}$ occurs normally in $\mathrm{PC} 2^{-1-}$ mice, probably catalyzed by another convertase.

\section{Distribution of PC1 and PC2 immunoreactivity in human cerebral cortex}

Immunoreactivity for PC1 (Fig. 2a-c) and PC2 (Fig. $2 d-f$ ) was detected in the human frontal and temporal cortex. Specific labeling was seen both in the soma and processes of immunopositive neurons (Fig. $2 \mathrm{a}-\mathrm{C}$ and $2 d-f)$. Numerous PC1- and PC2-immunoreactive (IR) soma, mainly found in the deep layers $\mathrm{V}$ and VI (illustrated for PC2; Fig. 2d), displayed similar patterns of distribution in the temporal and frontal cortex. Fewer IR cells were found in layers II and III (illustrated for PC1; Fig. 2a). Throughout the neuropil, PC1-IR elements appeared as small dots or fibers with large strongly immunopositive varicosities (Fig. 2 inset in b). They were widely distributed in all cortical layers and likely corresponded to axon fibers. At higher magnification, PC1 (Fig. 2c) and PC2 (Fig. 2f) immunoreactivities tended to form blob-shaped structures concentrated in the cytoplasm of neurons.

\section{Semi-quantification of PC1 and PC2 levels in the human frontal cortex}

As shown in Fig. 3a, the PC1 antibody detected a single molecular form of approximately $87 \mathrm{kDa}$ in human samples as well as in the rat frontal cortex. This product is likely to correspond to the $\mathrm{N}$-terminally truncated mature form of PC1 (Vindrola and Lindberg, 1992; Lindberg, 1994). As assessed by semi-quantitative analysis, no statistically significant change in PC1 levels was observed between C, B and demented patients although the latter groups, i.e. MD and $A D$ patients, tended to show a decrease as compared to $C$ (Fig. 3b).

In the same soluble fractions, PC2 was found as a minor form of $75 \mathrm{kDa}$ and a major form of $68 \mathrm{kDa}$ (Fig. 4a). The size of $75 \mathrm{kDa}$ form is consistent with that of the proenzyme (proPC2), and the size of $68 \mathrm{kDa}$ form with that of mature PC2 (Benjannet et al., 1993; Shennan et al., 1994). The apparent molecular mass of the proPC2 form differed somewhat in human $(71 \mathrm{kDa})$ compared to the rat 

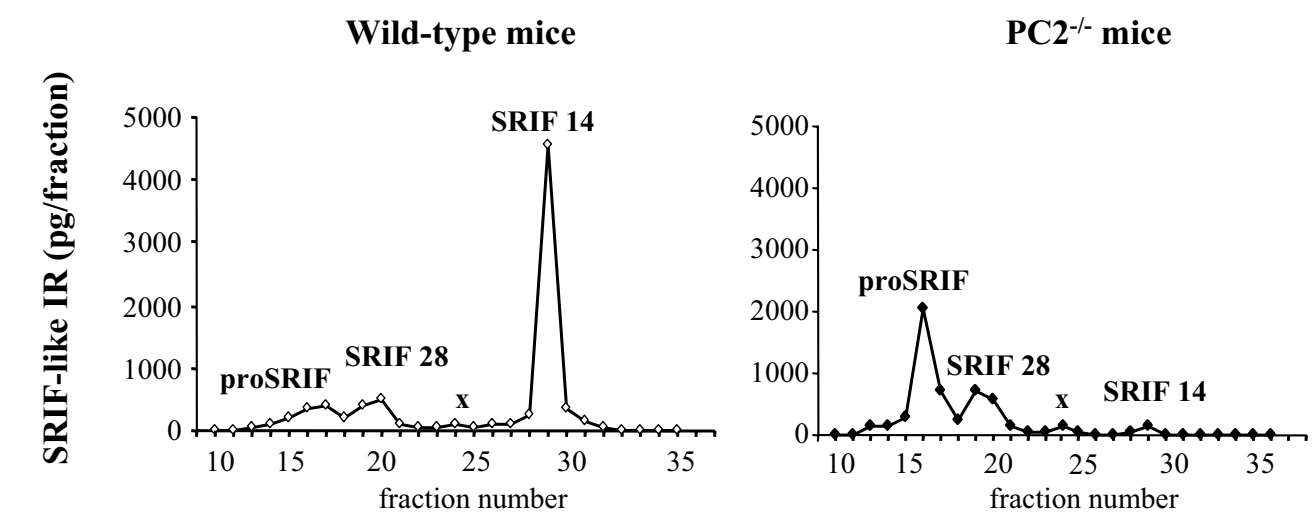

B

C
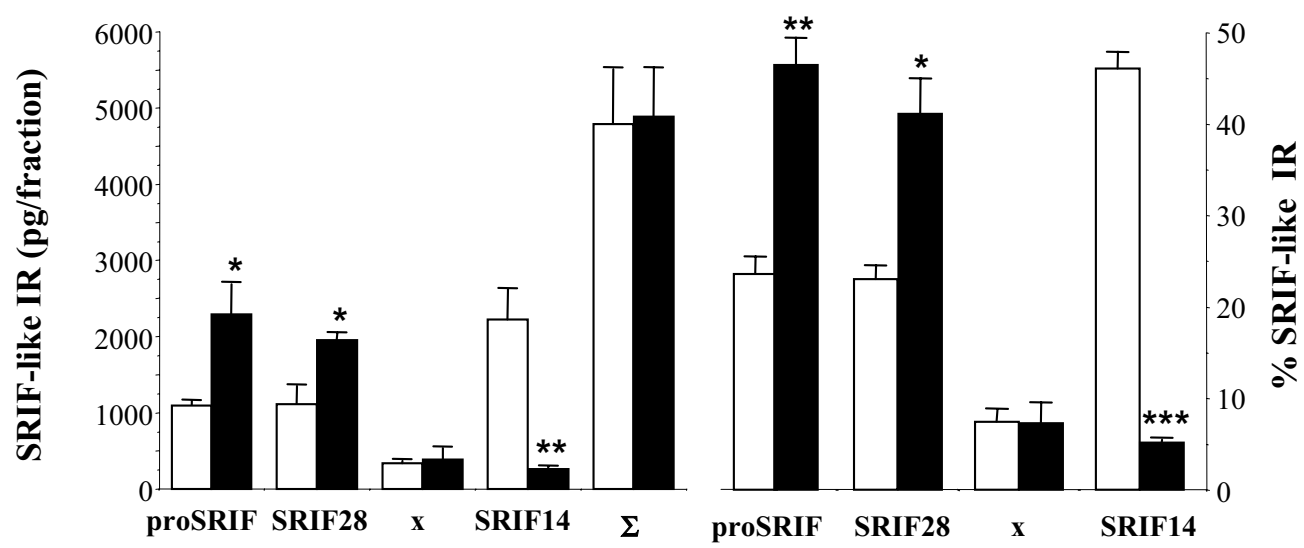

Fig. 1. Cortical prosomatostatin products in $\mathrm{PC} 2^{-1-}$ mice and corresponding WT. Representative chromatograms for cortical extracts from three different mice in each group. The chromatographic elution was monitored using a SRIF antibody that recognized proSRIF, SRIF28 and SRIF14 (A). Total SRIF-like IR $(\Sigma)$ and contents of proSRIF, SRIF28 and SRIF14 are expressed either as pg/fraction (B) or as percentage of total SRIF-like IR (C). Values are expressed as mean \pm S.E.M. ${ }^{*} P<0.05,{ }^{* *} P<0.01,{ }^{* * *} P<0.0001$.

$(75 \mathrm{kDa})$ soluble fraction. As shown in Fig. $4 \mathrm{~b}$, levels of the mature PC2 were similar in the four groups of patients. In contrast, there was a marked decrease in the levels of the proenzyme in MD as well as in AD patients as compared to $\mathrm{C}$ (Fig. 4c) and the ratio proPC2/(PC2+ proPC2) was significantly reduced in $A D$ patients $(P<0.05$; Fig. $4 d)$. No significant change was observed for the $B$ group. Furthermore, levels of proPC2 correlated with those of the mature enzyme $(r=0.43 ; P=0.035)$.

\section{Levels of 7B2 in human frontal cortex}

A Western blot obtained with the anti N-terminal 7B2 antibody is shown in Fig. 5a. In rat frontal cortex, a single weak band of around $27 \mathrm{kDa}$ was observed and is likely to correspond to the precursor protein (Ayoubi et al., 1990; Paquet et al., 1991). Three main immunoreactive bands were detected in human samples with a respective apparent size of 35,31 and $30 \mathrm{kDa}$. These three forms are present in nearly equivalent amounts and may represent various forms of the 7B2 precursor (pro7B2). In addition, a minor form of $21 \mathrm{kDa}$ showed a weak immunoreactivity. This $21 \mathrm{kDa}$ species may correspond to the product of the proteolytic maturation of pro7B2 (Martens, 1988). To control the specificity of the four bands detected in our study, negative controls were done by preadsportion of 7B2 antibody with the synthetic peptide. Specificity was demonstrated by a significant diminution of the immunoreactive signal for the presumptive precursor forms $(-75 \%)$ and the total abolition of the $21 \mathrm{kDa}$ signal (data not shown).

As shown in Fig. $5 \mathrm{~b}, \mathrm{C}$ and $\mathrm{B}$ patients displayed similar contents of the $35 \mathrm{kDa}$ precursor of $7 \mathrm{~B} 2$. There was, on the other hand, an increase in MD and AD patients compared to $C$ and this increase was significant for the $A D$ group $(P<0.05)$. The levels of the $31 \mathrm{kDa}$ and the $30 \mathrm{kDa}$ pro7B2 forms were similar to those found for the $35 \mathrm{kDa}$ species in the different patient groups (data not shown). Moreover, a significant correlation was found between the levels of these three presumptive precursor forms of 7B2 $(r=0.759$; $P<0.0001$ and $r=0.766 ; P<.0001$, respectively for the $31 \mathrm{kDa}$ and the $30 \mathrm{kDa}$ forms). No modification in the quantities of the cleaved $21 \mathrm{kDa} 7 \mathrm{~B} 2$ form was detected between the different groups (Fig. $5 \mathrm{c}$ ). Hence, the ratio pro7B2/(7B2+ pro7B2) was significantly increased in $A D$ patients $(P<0.05$; Fig. $5 d)$. 

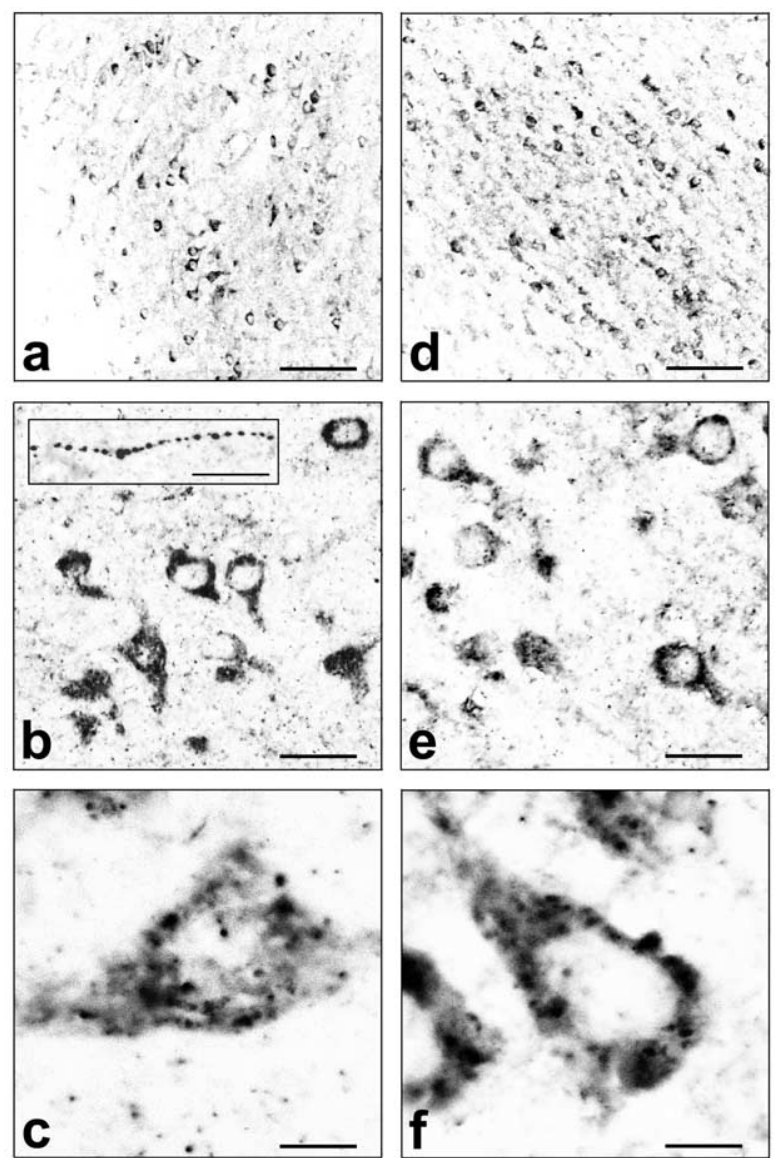

Fig. 2. Immunohistochemical staining of $P C 1(a-c)$ and $P C 2(d-f)$ in human frontal cortex of a $C$ patient. IR neurons are shown in the superficial layer II and III for PC1 (a) and in the deep layer VI for PC2 (d). PC1 (b) and PC2 (e) IRs are present in the soma and processes of neurons, as well as in fibers with large varicosities for PC1 (frame in b). At higher magnification (c, f), IR for both enzymes was present at the level of blob-shaped structures within the cytoplasm and also near the base of the dendrites. Scale bars $=(a, d) 120 \mu \mathrm{m}$; (b, c) $30 \mu \mathrm{m}$; (c, f) $8 \mu \mathrm{m}$; frame in b, $4 \mu \mathrm{m}$.

Linear regressions analysis showed that the levels of PC1 as well as the various forms of PC2 and 7B2 detected were not correlated with postmortem delay nor age at death. On the other hand, a significant correlation was observed between the amounts of PC2 and the cleaved form of 7B2 ( $\mathrm{r}=0.55, P=0.0056$; Fig. 6a). Levels of the 7B2 precursor were also found to statistically correlate with $\beta$-amyloid contents ( $r=0.63, P=0.0013$; Fig. $6 b)$.

\section{PC2 activity in human frontal cortex}

In order to determine whether the detected PC2 mature species were actually enzymatically active, PC2 activity was measured in the different groups of patients. PC2 activity was similar between the four groups (Fig. 7). Taken together with the Western blot analysis, the data indicated that mature PC2 enzyme was present and active in AD patients, although there was a decrease in the ratio of proPC2 to the total enzymatic pool.

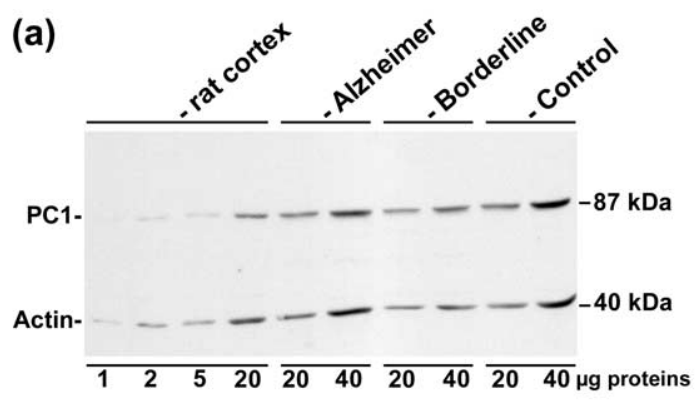

(b)

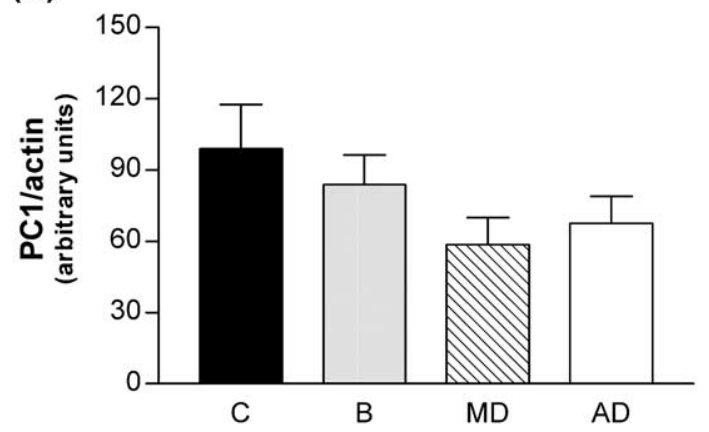

Fig. 3. Semi-quantification of PC1 levels by Western blot. (a) Representative Western blot of soluble fractions from rat and human (Brodmann 9 area) frontal cortices. Results are shown for one $A D$, one $B$ and one $C$ patient. Membranes were probed simultaneously with antisera against the C-terminal part of PC1 and actin antibody. Proteins of the expected molecular mass were detected. The amount of soluble fraction proteins applied per well is given on the lower part of the panel. (b) Semi- quantification of PC1 contents from frontal cortex soluble fractions of human patients. Proteins levels were estimated by scanning densitometry of immunoblots detected with PC1 and actin antisera. PC1 amounts were normalized by actin contents. Protein levels in each sample were obtained by calculating the mean of densitometric values obtained for the two loaded quantities. Semiquantification is based on a total of seven $C$, six B, four MD and seven $A D$ patients. Results are shown as mean values \pm S.E.M.

\section{DISCUSSION}

The proprotein convertases PC1 and PC2 are known to participate in the generation of bioactive neuropeptides by specific proteolytic processing of inactive precursors at basic amino acids sites (for review, see Seidah and Chretien, 1999). In the present study, we demonstrated that prosomatostatin is a physiological substrate of PC2 in vivo and that generation of brain SRIF14 from precursor requires this convertase. These results are in keeping with the study of Furuta et al. (1997) which showed that the processing of proSRIF is severely impaired in $\mathrm{PC}^{-1-}$ mice pancreatic islets. Furthermore, PC1 and PC2 immunoreactivities are localized in numerous human cortical neurons and their topographic and cellular distribution broadly coincides with that previously reported in the rat cerebral cortex, i.e. mainly in the cortical layers II, III, as well as V and VI (Winsky-Sommerer et al., 2000). This includes pyramidal cells as well as interneurons. According to primate studies, specific neuronal classes in which somatostatin would be found are likely to be double-bouquet interneurons (de Lima and Morrison, 1989), a subclass of interneurons which is incidentally known to be resistant to 


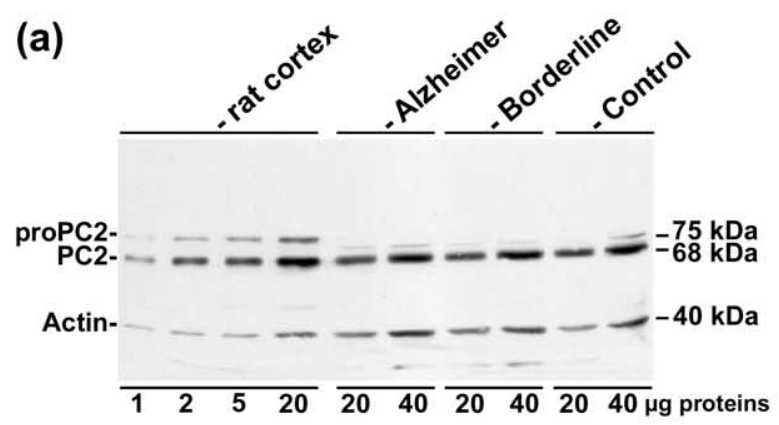

(b)

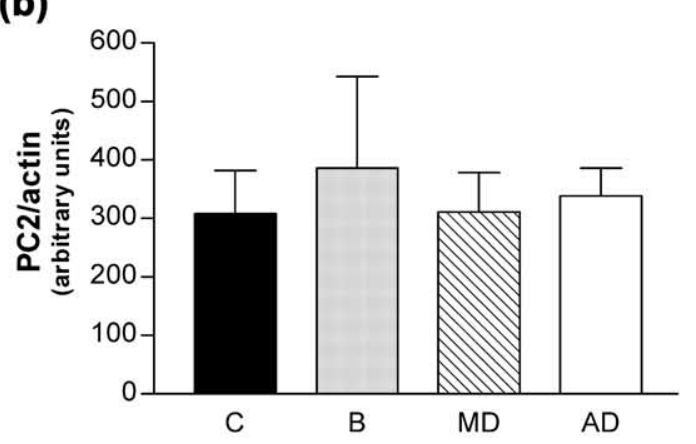

(c)

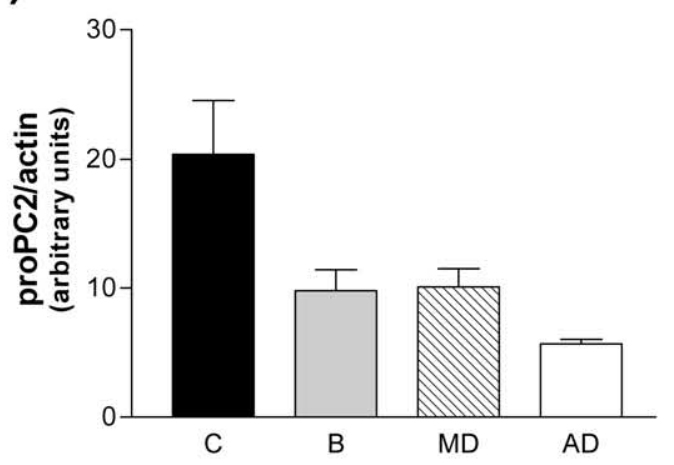

(d)

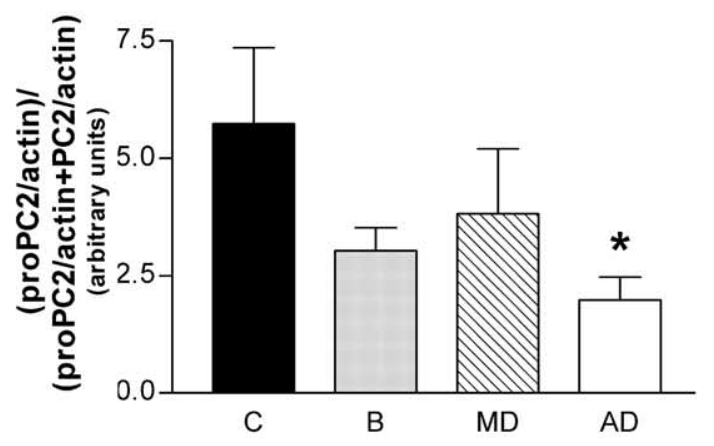

Fig. 4. Semi-quantification of PC2 levels by Western blot. (a) Representative Western blot of frontal cortices soluble fractions from rat and human patients. Membranes were probed simultaneously with antisera against the C-terminal portion of PC2 and actin antibody. The amount of soluble fraction proteins applied per well is given on the lower part of the panel. (b) and (c) Semi-quantification of PC2 (b) and proPC2 (c) contents in frontal cortex soluble fractions of human patients. (d) Values for the ratio proPC2/(PC2+ proPC2) were also reported. Analysis of densitometric scanning of immunoblots was performed as described for PC1 in Fig. 2b. Values are mean \pm S.E.M. of the degenerative process of $A D$ until late in the disease (Hof et al., 1993). SRIF-containing interneurons are primarily found in layer III, V and VI and immunoreactive fibers are distributed in all layers (Braak et al., 1985; Beal and Martin, 1986; Bouras et al., 1986; Hornung et al., 1992). Thus, localization of PC1 and PC2 is consistent with their putative role in activation of regulatory peptides in vivo, such as proSRIF.

If the loss of SRIF-like immunoreactivity observed in the frontal cortex was due to death of somatostatinergic interneurons, a parallel loss of all somatostatinergic forms would be expected. Pierotti et al. (1986) observed that the proportion of proSRIF was significantly lower in the temporal cortex of AD patients and SRIF28 proportions were significantly elevated. These results suggested that total SRIF deficiency was related to a reduction in the rate of biosynthesis and/or to a change in the proteolytic processing of the precursor form to yield the bioactive peptides SRIF28 and SRIF14. Thus, we investigated whether a modification in the expression of the enzymes responsible for the maturation of proSRIF were involved in changing of proSRIF maturation pattern.

For both convertases, Western blotting revealed similar molecular forms in human cerebral cortex to those previously reported in various mammalian tissues, as well as in cells transfected with the cDNA encoding each enzyme (Paquet et al., 1996; Rovere et al., 1996; Dong et al., 1997; Muller et al., 1998). The slower migration on SDSPAGE of rat proPC2 as compared to human is most likely due to the fact that the rat prosegment sequence is more acidic ( $\mathrm{pl}$ 10.0) than that of human ( $\mathrm{pl} 10.7$ ).

Western blot semi-quantification indicated that among patients displaying cognitive and/or behavioral impairment, modifications in the levels of both convertases were observed only in demented patients, for whom alterations of neuropeptidergic systems have been previously documented. The moderate decrease of PC1 in MD and $A D$ patients was however not significant. It would be interesting to further determine to which extent PC1 activity is actually inhibited in AD; however an assay for PC1 in tissue extracts is not presently available. In parallel, we demonstrated an altered ratio of proPC2 to the total PC2 enzymatic pool in the frontal cortex of $A D$ patients.

In an attempt to understand why AD patients, in spite of a defect in proPC2 content, displayed similar levels of active PC2 compared to $C$ subjects, the levels of the neuroendocrine protein 7B2 (which is involved in proPC2 transport as well as activation) were determined (Zhu and Lindberg, 1995). 7B2 is a non-glycosylated protein synthesized as a polypeptide of predicted molecular mass of $18 \mathrm{kDa}$ migrating at around $29 \mathrm{kDa}$ upon SDS-PAGE (pro7B2), and proteolytically processed into an aminoterminal form of $21 \mathrm{kDa}$ (referred as the cleaved 7B2 Ayoubi et al., 1990; Paquet et al., 1991). By Western blot, four immunoreactive bands of 35, 31, 30 and $21 \mathrm{kDa}$ were

seven $C$, six $B$, four $M D$ and seven $A D$ patients. * Asterisk indicates $P<0.05$ versus controls. 


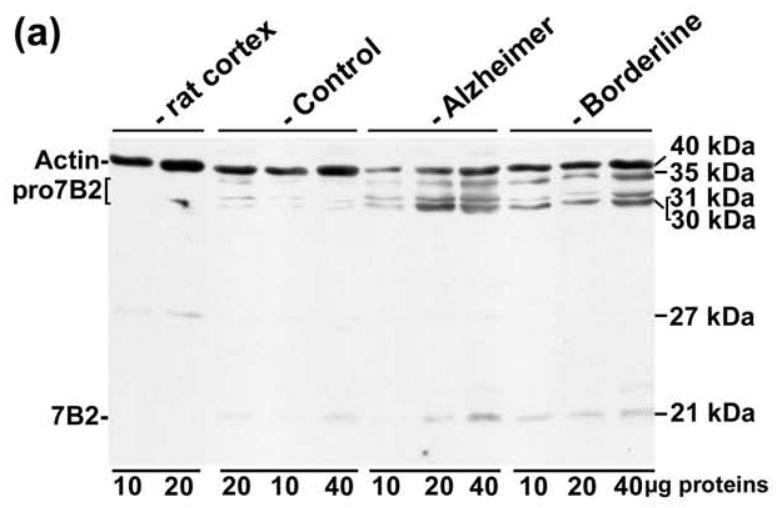

(b)

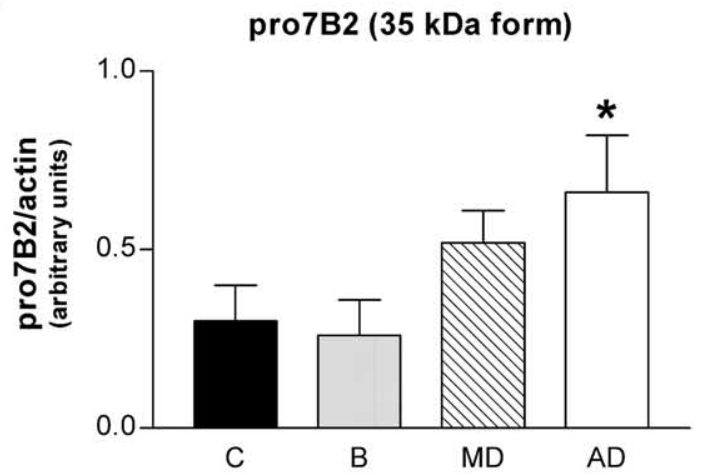

(c)

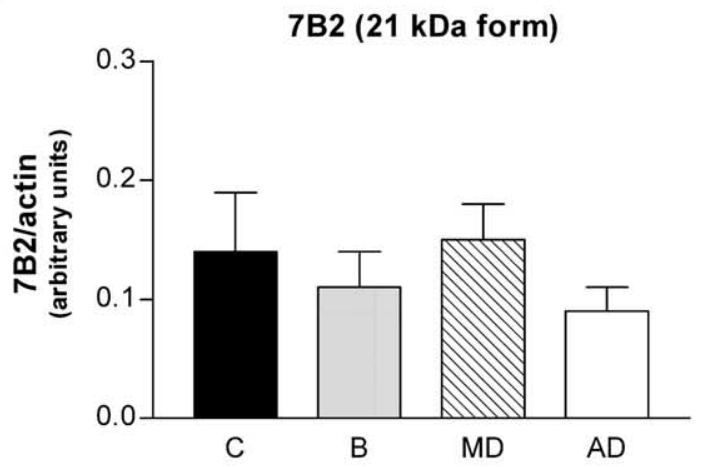

(d)

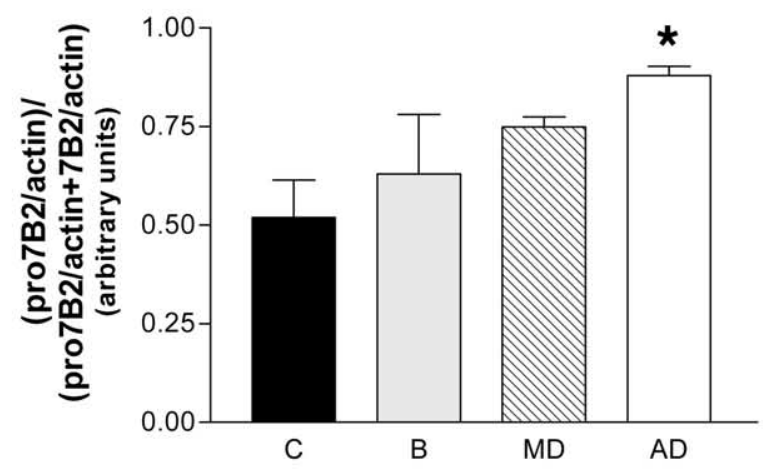

Fig. 5. Semi-quantification of 7B2 levels by Western blot. (a) Western blot immunodetected simultaneously with 7B2 and actin antibodies. A weak band is detected in rat cortex and is consistent with the $27 \mathrm{kDa}$ precursor form of 7B2. Four molecular forms of 7B2 were identified in human frontal cortex. Actin migrated at the expected molecular mass

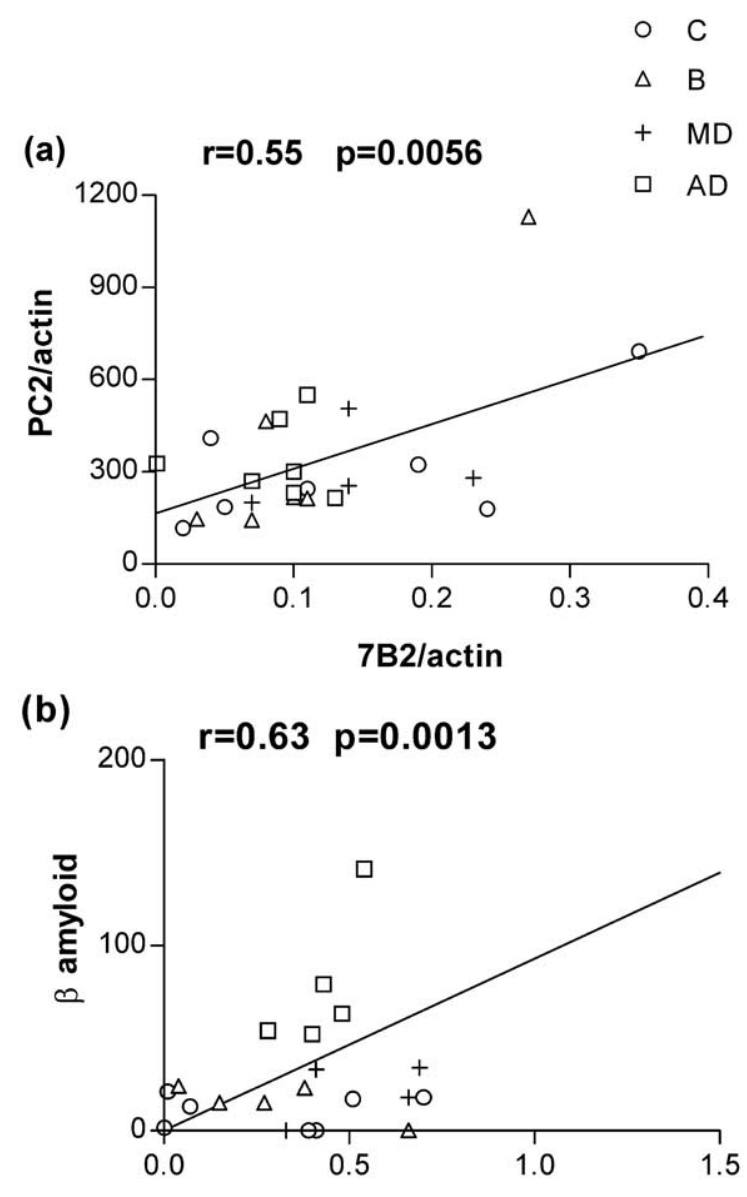

Fig. 6. Correlation curves between (a) levels of the mature $\mathrm{PC} 2$ form and amounts of the cleaved $21 \mathrm{kDa} 7 \mathrm{~B} 2$ (both in arbitrary units) in the frontal cortex (Brodmann 9 area) of C, B, MD and AD patients; and (b) between $\beta$-amyloid contents and levels of the 7B2 precursor (pro7B2; both in arbitrary units) in the same patients as in (a).

detected. In human tissue, the $35 \mathrm{kDa}$ and $21 \mathrm{kDa}$ forms have already been reported in corticotrophic pituitary tumours (Vieau et al., 1992). The additional precursor forms of 31 and $30 \mathrm{kDa}$ could potentially result from post-translational modifications such as sulfation events, since 7B2 was shown to be tyrosine-sulfated in the TGN before its processing (Paquet et al., 1994). Furthermore, SDS-PAGE analysis clearly overestimates the values of the 7B2 molecular masses. The discrepancies between the expected polypeptide mass and the apparent molecular mass detected by Western blot are presumably due to the abundance of acidic amino acid residues, as previously reported for other highly acidic proteins such as chromo-

of $40 \mathrm{kDa}$. The amount of soluble fraction proteins applied per well is given on the lower part of the panel. (b) and (c) correspond to the quantification of the $35 \mathrm{kDa}$ form of pro7B2 and the cleaved $21 \mathrm{kDa}$ 7B2, respectively. (d) Corresponds to the ratio pro7B2/(7B2+ pro7B2). Relative specific contents of the proteins were evaluated as described in Fig. $2 b$. Values are mean \pm S.E.M. of seven $C$, six $B$, four $\mathrm{MD}$ and seven $\mathrm{AD}$ patients. ${ }^{*}$ Asterisk indicates $P<0.05$ versus controls. 


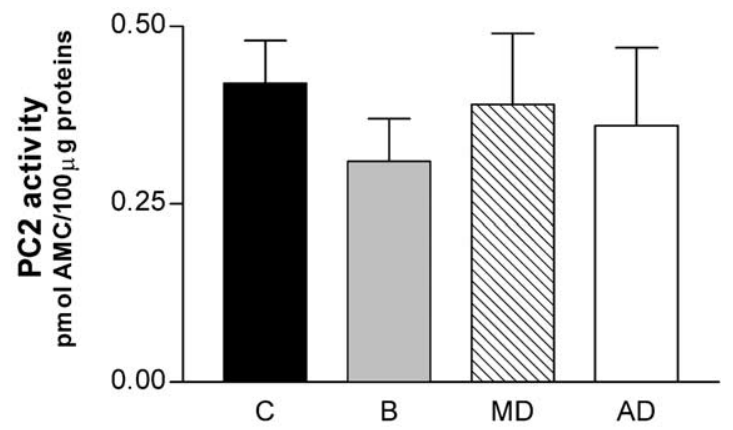

Fig. 7. Enzymatic activity of PC2 in human frontal cortex (Brodmann 9 area). Data are mean values \pm S.E.M. of triplicate determinations from seven $C$, six $B$, four $M D$ and seven $A D$ patients. Results are expressed in pmol $\mathrm{AMC} / 100 \mu \mathrm{g}$ of proteins.

granin A and chromogranin B (Wiedenmann and Huttner, 1989).

For the neuroendocrine protein 7B2, even though we demonstrated a clear increase of the uncleaved form in $A D$ patients, no change was observed for the cleaved form. Levels of 7B2 have previously been determined in human frontal cortex, caudate putamen and hippocampus and reported not to be altered in AD (Iguchi et al., 1987). However, these authors did not examine each molecular forms of 7B2.

The decrease in the ratio of proPC2 to the total enzymatic PC2 pool coincided with an increase of pro7B2 in the frontal cortex. Indeed, a significant correlation was observed between cleaved 7B2 and PC2 amounts. This suggests that failure to produce active PC2, due to the low levels of its precursor, could be balanced by the increase of pro7B2. In vitro studies have shown that pro7B2 increased proPC2 transport to the Golgi apparatus and was also required for proPC2 activation (Muller et al., 1997). Thus, the increased levels of pro7B2 could lead to an increase in the rate of the production of mature PC2. Modifications of 7B2 levels leading to change in proPC2 proteolytic conversion in vivo have already been reported. Indeed, Seidel et al. (1998) demonstrated, in an animal model of insulin-induced hypoglycemic shock, that a reduction of adrenal 7B2 levels correlated with a significant increase in the ratio of proPC2 compared to mature PC2. Furthermore, the protein 7B2 is required for PC2 activity in vivo as shown in 7B2 null mice which lack PC2 activity and present multiple metabolic impairments (Westphal et al., 1999). This is also in agreement with results obtained for 7B2 (+/-) heterozygote mice which exhibited the same amount of PC2 activity in tissue extracts as WT mice, while displaying only half of the WT PC2 contents (Dubey and Lindberg, unpublished results). Since the content of mature PC2 is not modified in the AD group, and since the four groups showed similar levels of PC2 activity, we conclude that cortical neuropeptide alterations observed in $A D$ patients do not result from a defect in PC2-mediated processing.

Interestingly, a relationship between increased levels of pro7B2 and $\beta$-amyloid content was observed. In addition to binding PC2, 7B2 might have an alternative function related to the secretory pathway. Whereas 7B2 and PC2 are clearly colocalized in rat brain neurons, 7B2 is more widely distributed than PC2, with many 7B2-positive neurons lacking PC2 expression (Seidel et al., 1998). Moreover, the intracellular localization of 7B2 in dense-core vesicles of neurons and endocrine cells (Iguchi et al., 1984; Marcinkiewicz et al., 1986) led to the hypothesis that it is associated with the regulatory secretory pathway of protein trafficking (Marcinkiewicz et al., 1987).

In conclusion, we here provide in vivo evidence that 1) the proprotein convertase PC2 is involved in the processing of proSRIF to SRIF14 in mouse brain, 2) PC1 and PC2, as well as its helper protein 7B2 are present in the human cortex to fullfill their proprotein convertases role on neuropeptide precursors and 3 ) alteration in cortical somatostatin associated with $A D$ is unlikely to be due to a defect in the convertase PC2. The issue of a selective neuronal vulnerability of a subclass of somatostatin interneurons remains to be investigated.

Acknowledgements-The authors would like to thank Dr. Tanja Ouimet for helpful discussions on the semi- quantitative Westernblot optimization. The skillfull assistance of Dr. Zsolt Csaba for the figures is gratefully acknowledged. Raphaëlle Winsky-Sommerer was a recipient of a fellowship from France Alzheimer. This work was financed by INSERM and EC Grant QIG3- CT-1999-00908 to Jacques Epelbaum.

\section{REFERENCES}

Ang LC, Shul DD (1995) Peptidergic neurons of subcortical white matter in aging and Alzheimer's brain. Brain Res 674:329-335.

Ayoubi TA, van Duijnhoven HL, van de Ven WJ, Jenks BG, Roubos EW, Martens GJ (1990) The neuroendocrine polypeptide 7B2 is a precursor protein. J Biol Chem 265:15644-15647.

Bancaud J, Ribet MF, Chagot D (1975) Proceedings: comparison between discharges of subclinical spikes and clinical epileptic attacks in patients with epilepsy. Electroencephalogr Clin Neurophysiol 39:554.

Beal MF (1990) Somatostatin in neurodegenerative illnesses. Metabolism 39:116-119.

Beal MF, Martin JB (1986) Neuropeptides in neurological disease. Ann Neurol 20:547-565.

Benjannet S, Reudelhuber T, Mercure C, Rondeau N, Chretien M, Seidah NG (1992) Proprotein conversion is determined by a multiplicity of factors including convertase processing, substrate specificity, and intracellular environment: cell type-specific processing of human prorenin by the convertase PC1. J Biol Chem 267:1141711423.

Benjannet S, Rondeau N, Paquet L, Boudreault A, Lazure C, Chretien M, Seidah NG (1993) Comparative biosynthesis, covalent posttranslational modifications and efficiency of prosegment cleavage of the prohormone convertases PC1 and PC2: glycosylation, sulphation and identification of the intracellular site of prosegment cleavage of PC1 and PC2. Biochem J 294:735-743.

Bennett GW, Ballard TM, Watson CD, Fone KC (1997) Effect of neuropeptides on cognitive function. Exp Gerontol 32:451-469.

Bissette G, Myers B (1992) Somatostatin in Alzheimer's disease and depression. Life Sci 51:1389-1410.

Bouras C, Magistretti PJ, Morrison JH (1986) An immunohistochemical study of six biologically active peptides in the human brain. Hum Neurobiol 5:213-226.

Braak E, Braak H, Weindl A (1985) Somatostatin-like immunoreactivity in non-pyramidal neurons of the human isocortex. Anat Embryol (Berl) 173:237-246. 
Cummings JL (1987) Dementia syndromes: neurobehavioral and neuropsychiatric features. J Clin Psychiatry 48 (Suppl):3-8.

Cummings JL, Miller B, Hill MA, Neshkes R (1987) Neuropsychiatric aspects of multi-infarct dementia and dementia of the Alzheimer type. Arch Neurol 44:389-393.

de Lima AD, Morrison JH (1989) Ultrastructural analysis of somatostatin-immunoreactive neurons and synapses in the temporal and occipital cortex of the macaque monkey. J Comp Neurol 283:212227.

Delacourte A, David JP, Sergeant N, Buee L, Wattez A, Vermersch P, Ghozali F, Fallet- Bianco C, Pasquier F, Lebert F, Petit H, Di Menza C (1999) The biochemical pathway of neurofibrillary degeneration in aging and Alzheimer's disease. Neurology 52:1158-1165.

Dong W, Seidel B, Marcinkiewicz M, Chretien M, Seidah NG, Day R (1997) Cellular localization of the prohormone convertases in the hypothalamic paraventricular and supraoptic nuclei: selective regulation of PC1 in corticotrophin-releasing hormone parvocellular neurons mediated by glucocorticoids. J Neurosci 17:563-575.

Dournaud P, Delaere P, Hauw JJ, Epelbaum J (1995) Differential correlation between neurochemical deficits, neuropathology, and cognitive status in Alzheimer's disease. Neurobiol Aging 16:817823.

Folstein MF, Folstein SE, McHugh PR (1975) "Mini-mental state": a practical method for grading the cognitive state of patients for the clinician. J Psychiatr Res 12:189-198.

Furuta M, Yano H, Zhou A, Rouille Y, Holst JJ, Carroll R, Ravazzola M, Orci L, Furuta H, Steiner DF (1997) Defective prohormone processing and altered pancreatic islet morphology in mice lacking active SPC2. Proc Natl Acad Sci USA 94:6646-6651.

Galanopoulou AS, Kent G, Rabbani SN, Seidah NG, Patel YC (1993) Heterologous processing of prosomatostatin in constitutive and regulated secretory pathways. Putative role of the endoproteases furin, PC1, and PC2. J Biol Chem 268:6041-6049.

Grouselle D, Winsky-Sommerer R, David JP, Delacourte A, Dournaud $P$, Epelbaum J (1998) Loss of somatostatin-like immunoreactivity in the frontal cortex of Alzheimer patients carrying the apolipoprotein epsilon 4 allele. Neurosci Lett 255:21-24.

Hof PR, Nimchinsky EA, Celio MR, Bouras C, Morrison JH (1993) Calretinin-immunoreactive neocortical interneurons are unaffected in Alzheimer's disease. Neurosci Lett 152:145-148.

Hornung JP, De Tribolet N, Tork I (1992) Morphology and distribution of neuropeptide-containing neurons in human cerebral cortex. Neuroscience 51:363-375

Hughes CP, Berg L, Danziger WL, Coben LA, Martin RL (1982) A new clinical scale for the staging of dementia. Br J Psychiatry 140:566572.

Iguchi H, Chan JS, Seidah NG, Chretien M (1984) Tissue distribution and molecular forms of a novel pituitary protein in the rat. Neuroendocrinology 39:453-458.

Iguchi H, Chan JS, Seidah NG, Chretien M (1987) Evidence for a novel pituitary protein (7B2) in human brain, cerebrospinal fluid and plasma: brain concentrations in controls and patients with Alzheimer's disease. Peptides 8:593-598.

Laemmli UK (1970) Cleavage of structural proteins during the assembly of the head of bacteriophage T4. Nature 227:680-685.

Leake A, Perry EK, Perry RH, Jabeen S, Fairbairn AF, McKeith IG, Ferrier IN (1991) Neocortical concentrations of neuropeptides in senile dementia of the Alzheimer and Lewy body type: comparison with Parkinson's disease and severity correlations. Biol Psychiatry 29:357-364.

Lindberg I (1994) Evidence for cleavage of the PC1/PC3 pro-segment in the endoplasmic reticulum. Mol Cell Neurosci 5:263-268.

Lindberg I, van den Hurk WH, Bui C, Batie CJ (1995) Enzymatic characterization of immunopurified prohormone convertase 2: potent inhibition by a 7B2 peptide fragment. Biochemistry $34: 5486-$ 5493.

Marcinkiewicz M, Day R, Seidah NG, Chretien M (1993) Ontogeny of the prohormone convertases PC1 and PC2 in the mouse hypoph- ysis and their colocalization with corticotropin and alpha-melanotropin. Proc Natl Acad Sci USA 90:4922-4926.

Marcinkiewicz M, Benjannet S, Cantin M, Seidah NG, Chretien M (1986) CNS distribution of a novel pituitary protein '7B2': localization in secretory and synaptic vesicles. Brain Res 380:349-356.

Marcinkiewicz M, Benjannet S, Seidah NG, Cantin M, Chretien M (1987) The pituitary polypeptide "7B2" is associated with LH/FSH and TSH cells and is localized within secretory vesicles. Cell Tissue Res 250:205-214.

Martens GJ (1988) Cloning and sequence analysis of human pituitary cDNA encoding the novel polypeptide 7B2. FEBS Lett 234:160164.

Martens GJ, Braks JA, Eib DW, Zhou Y, Lindberg I (1994) The neuroendocrine polypeptide $7 \mathrm{~B} 2$ is an endogenous inhibitor of prohormone convertase PC2. Proc Natl Acad Sci USA 91:5784-5787.

McKhann G, Drachman D, Folstein M, Katzman R, Price D, Stadlan EM (1984) Clinical diagnosis of Alzheimer's disease: report of the NINCDS-ADRDA Work Group under the auspices of Department of Health and Human Services Task Force on Alzheimer's Disease. Neurology 34:939-944.

Moroney JT, Bagiella E, Desmond DW, Hachinski VC, Molsa PK, Gustafson L, Brun A, Fischer P, Erkinjuntti T, Rosen W, Paik MC, Tatemichi TK (1997) Meta-analysis of the Hachinski Ischemic Score in pathologically verified dementias. Neurology 49:10961105.

Muller L, Lindberg I (1999) The cell biology of the prohormone convertases PC1 and PC2. Prog Nucleic Acid Res Mol Biol 63:69-108.

Muller L, Zhu X, Lindberg I (1997) Mechanism of the facilitation of PC2 maturation by 7B2: involvement in proPC2 transport and activation but not folding. J Cell Biol 139:625-638.

Muller L, Picart R, Barret A, Seidah NG, Tougard C (1998) Immunocytochemical localization of the prohormone convertases PC1 and PC2 in rat prolactin cells. J Histochem Cytochem 46:101-108.

Nieuwenhuys R, Voogd J, Van Huijzen C (1988) The human central nervous system: a synopsis and atlas, 3rd edition (revised). Berlin: Springler-Verlag.

Paquet L, Massie B, Mains RE (1996) Proneuropeptide Y processing in large dense-core vesicles: manipulation of prohormone convertase expression in sympathetic neurons using adenoviruses. J Neurosci 16:964-973.

Paquet L, Rondeau N, Seidah NG, Lazure C, Chretien M, Mbikay M (1991) Immunological identification and sequence characterization of a peptide derived from the processing of neuroendocrine protein 7B2. FEBS Lett 294:23-26.

Paquet L, Bergeron F, Boudreault A, Seidah NG, Chretien M, Mbikay M, Lazure C (1994) The neuroendocrine precursor 7B2 is a sulfated protein proteolytically processed by a ubiquitous furin-like convertase. J Biol Chem 269:19279-19285.

Perone MJ, Ahmed I, Linton EA, Castro MG (1996) Procorticotrophin releasing hormone is endoproteolytically processed by the prohormone convertase $\mathrm{PC} 2$ but not by $\mathrm{PC} 1$ within stably transfected CHO-K1 cells. Biochem Soc Trans 24:497S.

Perry EK, Blessed G, Tomlinson BE, Perry RH, Crow TJ, Cross AJ, Dockray GJ, Dimaline R, Arregui A (1981) Neurochemical activities in human temporal lobe related to aging and Alzheimer-type changes. Neurobiol Aging 2:251-256.

Pierotti A, Harmar A, Simpson J, Yates C (1986) High-molecular weight forms of somatostatin are reduced in Alzheimer's disease and Down's sydrome. Neurosci Lett 63:141-146.

Reinikainen KJ, Riekkinen PJ, Jolkkonen J, Kosma VM, Soininen H (1987) Decreased somatostatin-like immunoreactivity in cerebral cortex and cerebrospinal fluid in Alzheimer's disease. Brain Res 402:103-108.

Rorstad OP, Epelbaum J, Brazeau P, Martin JB (1979) Chromatographic and biological properties of immunoreactive somatostatin in hypothalamic and extrahypothalamic brain regions of the rat. Endocrinology 105:1083-1092. 
Rovere C, Barbero P, Kitabgi P (1996) Evidence that PC2 is the endogenous pro-neurotensin convertase in rMTC $6-23$ cells and that PC1- and PC2-transfected PC12 cells differentially process pro-neurotensin. J Biol Chem 271:11368-11375.

Rubinow DR, Davis CL, Post RM (1992) Somatostatin in neuropsychiatric disorders. Basic Clin Aspects Neurosci 4:29-42.

Sadow TF, Rubin RT (1992) Effects of hypothalamic peptides on the aging brain. Psychoneuroendocrinology 17:293-314.

Seidah NG, Chretien M (1999) Proprotein and prohormone convertases: a family of subtilases generating diverse bioactive polypeptides. Brain Res 848:45-62.

Seidel B, Dong W, Savaria D, Zheng M, Pintar JE, Day R (1998) Neuroendocrine protein 7B2 is essential for proteolytic conversion and activation of proprotein convertase 2 in vivo. DNA Cell Biol 17:1017-1029.

Shennan KI, Taylor NA, Docherty K (1994) Calcium- and pH-dependent aggregation and membrane association of the precursor of the prohormone convertase PC2. J Biol Chem 269:18646-18650.

Vieau D, Linard CG, Mbikay M, Lenne F, Chretien M, Luton JP, Bertagna $X$ (1992) Expression of the neuroendocrine cell marker
7B2 in human ACTH secreting tumours. Clin Endocrinol (Oxf) 36:597-603.

Vindrola O, Lindberg I (1992) Biosynthesis of the prohormone convertase mPC1 in AtT-20 cells. Mol Endocrinol 6:1088-1094.

Westphal CH, Muller L, Zhou A, Zhu X, Bonner-Weir S, Schambelan M, Steiner DF, Lindberg I, Leder P (1999) The neuroendocrine protein 7B2 is required for peptide hormone processing in vivo and provides a novel mechanism for pituitary Cushing's disease. Cell 96:689-700.

Wiedenmann B, Huttner WB (1989) Synaptophysin and chromogranins/secretogranins: widespread constituents of distinct types of neuroendocrine vesicles and new tools in tumor diagnosis. Virchows Arch B Cell Pathol Incl Mol Pathol 58:95-121.

Winsky-Sommerer R, Benjannet S, Rovere C, Barbero P, Seidah NG, Epelbaum J, Dournaud P (2000) Regional and cellular localization of the neuroendocrine prohormone convertases PC1 and PC2 in the rat central nervous system. J Comp Neurol 424:439-460.

Zhu X, Lindberg I (1995) 7B2 facilitates the maturation of proPC2 in neuroendocrine cells and is required for the expression of enzymatic activity. J Cell Biol 129:1641-1650. 